\title{
PENINGKATAN KINERJA RANTAI PASOK BAWANG MERAH (STUDI KASUS: KABUPATEN BREBES)
}

\section{PERFORMANCE IMPROVEMENT OF SHALLOTS SUPPLY CHAIN (CASE STUDY: BREBES DISTRICT)}

\author{
Lely Rachma Septiana, Machfud, dan Indah Yuliasih \\ ${ }^{1)}$ Program Studi Teknologi Industri Pertanian, Fakultas Teknologi Pertanian, Institut Pertanian Bogor \\ Kampus IPB Darmaga, Bogor 16680 \\ E-mail: uzma_rachma@yahoo.com
}

Makalah: Diterima 25 Agustus 2016; Diperbaiki 27 Januari 2017; Disetujui 5Februari 2017

\begin{abstract}
Shallots supply chain faces many problems and challenges, so need efforts to improve the performance. This study was conducted to: 1) analyze conditions of the shallots supply chain using the framework discussion of FSCN (Food Supply Chain Network), 2) measure performance of the shallots supply chain using the rating scale method and indicator assessment adapted from the SCOR (Supply Chain Operations Reference) model, and 3) formulate efforts to improve performance of shallots supply chain by conducting gap analysis and problem analysis. The study was conducted in Brebes as the largest shallots production center in Indonesia. The results showed that the members of shallots supply chain are farmers, traders, wholesalers, and retailers or traditional local market traders. The performance measurement to shallots supply chain in Brebes showed the value of 3.57 during the season and 3.28 in off season. Efforts to improve the supply chain performance of shallots in Brebes include building proper inventory system; build partnerships, coordination and collaboration among the members of the chain and institutional capacity building of farmers, address the low availability of shallots especially during the off season; increase the availability of market information; and solve the problems concerning the distribution mechanism.
\end{abstract}

Keywords: shallots, supply chain, performance measurement,performance improvement

\section{ABSTRAK}

Rantai pasok bawang merah menghadapi berbagai permasalahan sekaligus tantangan sehingga diperlukan upaya peningkatan kinerja. Studi ini dilakukan untuk 1) menganalisis kondisi rantai pasok bawang merah menggunakan kerangka pembahasan FSCN (Food Supply Chain Network), 2) mengukur kinerja rantai pasok bawang merahmenggunakan metode rating scale dan indikator penilaiannya diadaptasi dari model SCOR (Supply Chain Operations Reference), dan3) merumuskan upaya peningkatan kinerja rantai pasok bawang merah dengan melakukan analisis kesenjangan dan analisis masalah terlebih dahulu. Penelitian dilakukan di Kabupaten Brebes sebagai sentra produksi bawang merah terbesar di Indonesia. Hasil penelitian menunjukkan bahwa pelaku rantai pasok bawang merah di Kabupaten Brebes terdiri dari petani, pedagang pengumpul, pedagang besar, dan pedagang pengecer lokal atau pedagang pasar tradisional lokal. Hasil pengukuran kinerja rantai pasok bawang merah di Kabupaten Brebes pada saat in season lebih besar (skor 3,57) dibandingkan saat off season (skor 328). Upaya dalam meningkatkan kinerja rantai pasok bawang merah di Kabupaten ini antara lain membangun sistem persediaan yang tepat; membangun kemitraan, koordinasi dan kolaborasi diantara anggota rantai serta penguatan kelembagaan petani, mengatasi rendahnya ketersediaan bawang merah terutama saat off season;meningkatkan ketersediaan informasi pasar; dan mengatasi permasalahan mengenai mekanisme distribusi.

Kata kunci: bawang merah, rantai pasok, pengukuran kinerja, peningkatan kinerja

\section{PENDAHULUAN}

Bawang merah adalah salah satu komoditas unggulan nasional dan termasuk penyumbang devisa negara. Komoditas ini memiliki nilai ekonomis yang tinggi sehingga menjadi sumber penghasilan bagi masyarakat yang tinggal disekitar daerah sentra produksi seperti Kabupaten Brebes yang mengandalkan perekonomiannya pada usaha bawang merah. Kabupaten Brebes merupakan sentra produksi bawang merah terbesar di Indonesia yang mensuplai sekitar $75 \%$ kebutuhan bawang merah di
Provinsi Jawa Tengah dan mensuplai sekitar 23\% kebutuhan nasional (Pusdatin, 2015).

Kabupaten Brebes sebagai daerah penghasil bawang merah mendistribusikan bawangnya ke berbagai daerah di Indonesia karena tidak semua daerah mampu memproduksi bawang merah. Namun, proses distribusi dan pemasaran bawang merah menghadapi kendala mengingat kondisi geografis Indonesia yang berbentuk kepulauan. Persoalan tersebut dapat diatasi melalui pengelolaan sistem logistik yang efektif dan efisien. 
Logistik adalah proses strategis dalam mengelola pengadaan, pergerakan dan penyimpanan bahan, baik bahan jadi maupun bahan setengah jadi melalui sebuah organisasi serta saluran pemasaran (Christopher, 2011). Untuk memperoleh sistem logistik yang efektif dan efisien digunakan konsep manajemen rantai pasok (Supply Chain Management). Manajemen rantai pasok dapat membawa anggota rantai pada tingkat efisiensi dan efektifitas yang optimal sehingga diperoleh keuntungan yang tinggi. Hal ini karena rantai pasok yang efektif dan efisien dapat mengintegrasikan sumberdaya yang ada, mengurangi biaya logistik, meningkatkan efisiensi biaya logistik dan kualitas yang tinggi. Sebaliknya, jika rantai pasok yang inefisien akan membawa pada kerugian seperti tingginya biaya logistik, biaya pengelolaan informasi, sumberdaya tidak termanfaatkan dengan baik, dan berkurangnya kapasitas produksi (Fan et al., 2013). Manajemen rantai pasok yang tepat memberikan sebuah peluang strategis yang besar untuk menciptakan keunggulan bersaing (Heizer dan Render, 2010).

Pengelolaan rantai pasok bawang merah cukup kompleks. Sebagaimana komoditas pertanian lainnya, pengelolaan rantai pasok bawang merah memiliki karakteristik tertentu karena dipengaruhi oleh sistem produksi, bulky, perishable dan penurunan kualitas secara terus menerus (Marimin dan Magfiroh, 2010; Nagurney et al., 2013). Padahal, permintaan terhadap bawang merah terjadi setiap hari sedangkan pemenuhan kebutuhan konsumen harus senantiasa terpenuhi sehingga upaya peningkatan kinerja rantai pasok bawang merah menjadi sangat diperlukan agar kebutuhan pelanggan dan keuntungan pelaku usaha dapat tercapai.

Penelitian sebelumnya mengenai peningkatan kinerja rantai pasok komoditas pertanian telah banyak dilakukan antara Setiawan et al. (2011); Dinata et al. (2014); Jannah et al. (2015); dan Sucipta et al. (2016). Penelitian sejenis khusus untuk komoditas bawang merah sangat terbatas. Penelitian mengenai perbaikan rantai pasok bawang merah pernah dilakukan oleh Adiyoga et al. (2010)di wilayah Nganjuk (Jawa Timur) dan Buleleng (Bali) menggunakan analisis deskriptif dan analisis SWOT. Namun, penelitian tersebut tidak didasari atas pengukuran kinerja rantai pasok. Pengukuran kinerja merupakan elemen yang penting dalam pengambilan keputusan dalam merencanakan efektivitas kerja (Bhagwat dan Sharma, 2007). Model pengukuran kinerja harus dibuat sedemikian rupa sehingga kinerja organisasi dapat terukur dan tujuan organisasi serta efektivitas kerja tercapai (Thakkar et al., 2009).

Oleh karena itu, penelitian ini secara umum bertujuan untuk mencari upaya meningkatkan kinerja rantai pasok bawang merah yang diawali dengan pengukuran kinerja. Secara khusus tujuan penelitian adalah1) menganalisis kondisi i, 2) mengukur kinerja, dan3) merumuskan upaya peningkatan kinerja rantai pasok bawang merah di Kabupaten Brebes.

\section{METODE PENELITIAN}

\section{Landasan Pemikiran}

Pengusahaan bawang merah, meskipun sebagai komoditas unggulan, seringkali menghadapi berbagai kendala dalam memenuhipermintaan yang terjadi sepanjang waktu. Permintaan konsumen harus dipenuhi agar target keuntungan pelaku usaha dapat tercapai. Oleh karena itu, upaya peningkatan kinerja rantai pasok bawang merah menjadi sangat diperlukan.

Kabupaten Brebes sebagai penghasil bawang merah terbesar di Indonesia merupakan lokasi yang sangat strategis untuk dikaji untuk menemukan upaya peningkatan kinerja rantai pasok bawang merah. Dalam rangka merumuskan upaya peningkatan kinerja rantai pasok bawang merah, diperlukan kajian terlebih dahulu mengenai kondisi rantai pasok bawang merah. Pengkajian kondisi rantai pasok bawang merah di Kabupaten Brebes merujuk pada kerangka pembahasan FSCN (Food Supply Chain Network) yang dikembangkan oleh Van der Vorst (2006). Penggunaan kerangka pembahasan ini diharapkan dapat memperjelas kondisi rantai pasok tersebut yang hasilnya dijadikan sebagai input dalam melakukan pengukuran kinerja rantai pasok. Pengukuran kinerja dilakukan dengan metode rating scale. Indikator penilaian kinerja (metrik) diadaptasi dari model SCOR (Supply Chain Operations Reference). Untuk merumuskan upaya peningkatan kinerja, erlebih dahulu dilakukan analisis kesenjangan antara kinerja rantai pasok saat ini dengan kinerja rantai pasok yang diharapkan dan analisis masalah rantai pasok bawang merah.Selanjutnya, dirumuskan rekomendasi/upaya peningkatan kinerja rantai pasok bawang merah. Landasan pemikiran dapat dilihat pada Gambar 1.

\section{Tempat dan Waktu Penelitian}

Penelitian ini dilakukan di Kabupaten Brebes, Jawa Tengah terutama di beberapa kecamatan penghasil bawang merah seperti Kecamatan Brebes, Wanasari, Bulakamba, Tanjung, Losari, Ketanggungan, Larangan, Songgom, dan Jatibarang. Waktu pelaksanaan penelitian yaitu bulan Mei 2015 hingga April 2016. Pengukuran kinerja terhadap anggota rantai pasok bawang merah dilakukan pada musim kemarau (in season) yaitu bulan Mei-September tahun 2015 dan musim hujan (off season) yaitu pada bulan Oktober-April tahun 2016. 


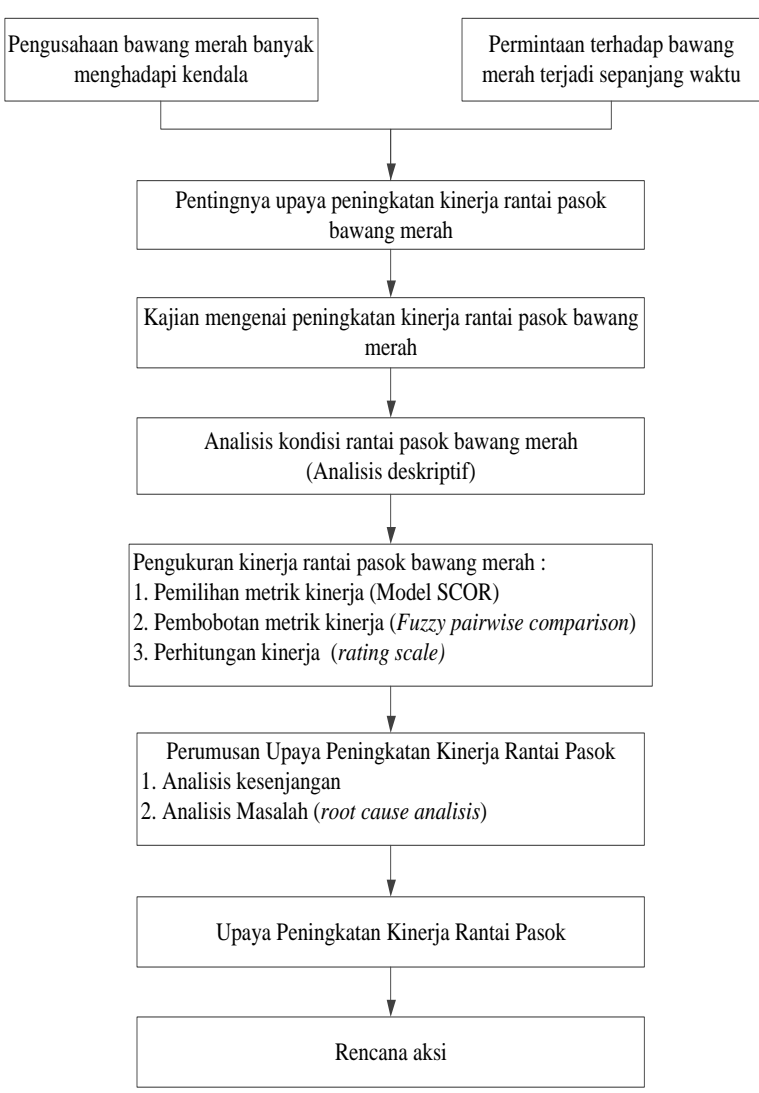

Gambar 1. Landasan pemikiran

\section{Pengumpulan dan Analisis Data}

Analisis Kondisi Rantai Pasok Bawang Merah

Kondisi rantai pasok bawang merah dibahas secara deskriptif mengikuti kerangka pembahasan FSCN (Food Supply Chain Network) yang dikembangkan oleh Van der Vorst (2006). Kerangka pembahasan tersebut mencakup aspek struktur rantai pasok, manajemen rantai pasok, sumber daya rantai pasok, dan proses bisnis rantai pasok. Data dan informasi diperoleh dengan menggunakan kuisioner dan in depth interview. Pemilihan responden pada analisis ini dilakukan dengan teknik snowball sampling yaitu dengan menelusuri saluran rantai pasok bawang merah di lokasi penelitian berdasarkan informasi yang didapat dari stakeholder terkait (petani, pedagang, konsumen rumah tangga, penyedia jasa transportasi dan angkutan, kelompok tani, gapoktan, asosiasi, serta Dinas terkait baik tingkat Kabupaten Brebes maupun pusat). Jumlah responden yang berhasil diwawancarai adalah 13 orang.

\section{Pengukuran Kinerja Rantai Pasok Bawang Merah}

Dalam mengukur kinerja rantai pasok bawang merah di Kabupaten Brebes, dilakukan tiga tahap diantaranya:

\section{Penentuan Metrik Kinerja}

Metrik (indikator penilaian) yang digunakan dalam mengukur kinerja rantai pasok bawang merah, diadaptasi dari model SCOR (Supply Chain Operations Reference). Model SCOR mencakup 134 indikator atau metrik penilaian yang mengukur kinerja proses rantai pasok (Paul, 2014). Penentuan metrik kinerja dilakukan dengan menganalisis hasil observasi dan wawancara mendalam kepada stakeholder terkait.

\section{Pembobotan Metrik Kinerja}

Pembobotan metrik kinerja dilakukan dengan menggunakan metode fuzzy AHP. Langkahlangkah pembobotan metrik yaitu dilakukan perbandingan skor dengan triangular fuzzy number, pembuatan matriks, penyelesaian nilai eigenfuzzy, dan penghitungan nilai CR (Consistency Ratio) (Marimim et al., 2013). Pembobotan metrik kinerja dilakukan dengan menggunakan kuisioner yang ditujukan kepada pelaku rantai pasok yang sudah berpengalaman dalam usaha bawang merah.

\section{Perhitungan Kinerja}

Bobot masing-masing metrik yang diperoleh dari metode fuzzy AHP digunakan dalam perhitungan kinerja rantai pasok bawang merah. Perhitungan total kinerja rantai pasok bawang merah dilakukan dengan menghitung nilai metrik kinerja dari level terendah, yaitu level tiga. Nilai metrik level tiga diperoleh dari hasil penilaian dengan menggunakan metode skala bertingkat (rating scale). Skala bertingkat merupakan alat ukur observasi yang berisi daftar pertanyaan dalam bentuk skala penilaian. Skala penilaian yang digunakan pada pengukuran kinerja rantai pasok bawang merah dapat dilihat pada Tabel 1. Penentuan responden pada penilaian (pengukuran) kinerja rantai pasok bawang merah menggunakan teknik purposive sampling yaitu pengambilan sampel berdasarkan pertimbangan-pertimbangan tertentu seperti keragaman objek penelitian serta keterbatasan dana, waktu, dan tenaga. Jumlah responden yang diambil sebagai sampel pengukuran kinerja rantai pasok bawang merah terdiri dari tiga orang pedagang besar, tiga orang pedagang pengumpul, dan tiga orang petani.

Tabel 1. Skala penilaian metrik kinerja pada atribut kinerja rantai pasok bawang merah

\begin{tabular}{clcccc}
\hline Skor & Reliabilitas & Responsivitas & Fleksibilitas & Biaya & Aset \\
\hline 1 & Buruk & Sangat lama & Sangat kurang & Sangat kurang & Sangat lama \\
2 & Kurang & Lama & Kurang & Kurang & Lama \\
3 & Cukup & Sedang & Cukup & Cukup & Sedang \\
4 & Baik & Cepat & Fleksibel & Efisien & Cepat \\
5 & Sangat baik & Sangat cepat & Sangat fleksibel & Sangat efisien & Sangat cepat \\
\hline
\end{tabular}


Setelah diperoleh nilai metrik level tiga, dilakukan perhitungan metrik level dua dan level satu. Nilai metrik level dua dan metrik level tiga, dihitung dengan menggunakan rumus persamaan 1 3. (modifikasi dari Arin et al., 2013).

$$
\begin{aligned}
& M_{2}=\sum_{i=1}^{n}\left(M_{3} \times \text { bobot }_{3}\right) \\
& M_{1}=\sum_{i=1}^{m}\left(M_{2} \times \text { bobot }_{2}\right) \\
& \text { Total }=\sum_{i=1}^{p}\left(M_{1} \times \text { bobot }_{1}\right)
\end{aligned}
$$

Keterangan :

$$
\begin{array}{lllll}
M_{3} & : & \text { metrik level } 3 & & \\
M_{2} & : & \text { metrik level } 2 & & \\
M_{1} & : & \text { metrik level 1 } & & \\
n & : & \text { metrik level } 3 \text { yang terdapat pada } \\
& \text { metrik level 2 } & & & \\
m & : & \text { metrik level } 2 \text { yang terdapat pada } \\
& \text { metrik level 1 } & & \\
p & : & \text { jumlah metrik level 1 }
\end{array}
$$

Perumusan Upaya Peningkatan Kinerja Rantai Pasok Bawang Merah

Upaya peningkatan kinerja rantai pasok bawang merah dirumuskan dengan melakukan 1) analisis kesenjangan antara kinerja aktual dengan kinerja yang diharapkan, 2) analisis masalah dengan metode analisis akar masalah (Root Cause Analysis), dan 3) penyusunan upaya peningkatan kinerja rantai pasok bawang merah. Analisis kesenjangan dilakukan dengan kuisioner terhadap pelaku rantai pasok (yang telah diukur kinerjanya) sedangkan analisis masalah dilakukan dengan observasi lapang dan brainstorming terhadap stakeholder terkait. Penyusunan upaya peningkatan kinerja rantai pasok bawang merah dilakukan berdasarkan analisis kesenjangan dan masalah serta studi literatur dan wawancara mendalam terhadap pakar (ahli dalam bidang rantai pasok bawang merah).

\section{HASIL DAN PEMBAHASAN}

\section{Analisis Kondisi Rantai Pasok Bawang Merah}

Struktur rantai pasok bawang merah yang ditemukan di Kabupaten Brebes dengan berbagai tujuan pasar dapat dilihat pada Gambar 2. Struktur rantai pasok bawang merah pada Gambar 1 menunjukkan panjangnya aliran bawang merah dari produsen hingga konsumen akhir. Akan tetapi pelaku rantai pasok bawang merah yang terdapat di Kabupaten Brebes hanya terdiri dari petani, pedagang pengumpul, pedagang besar, dan pedagang pengecer lokal atau pedagang pasar tradisional lokal. Struktur rantai pasok bawang merah tersebut juga menunjukkan beragamnya pola saluran pasokan bawang merah. Rantai pasok bawang merah di Kabupaten Brebes dengan tujuan konsumen akhir dapat diidentifikasi menjadi 12 saluran. Pola aliran barang yang terbentuk umumnya telah berjalan dalam jangka waktu yang lama dan terbentuk secara alami.

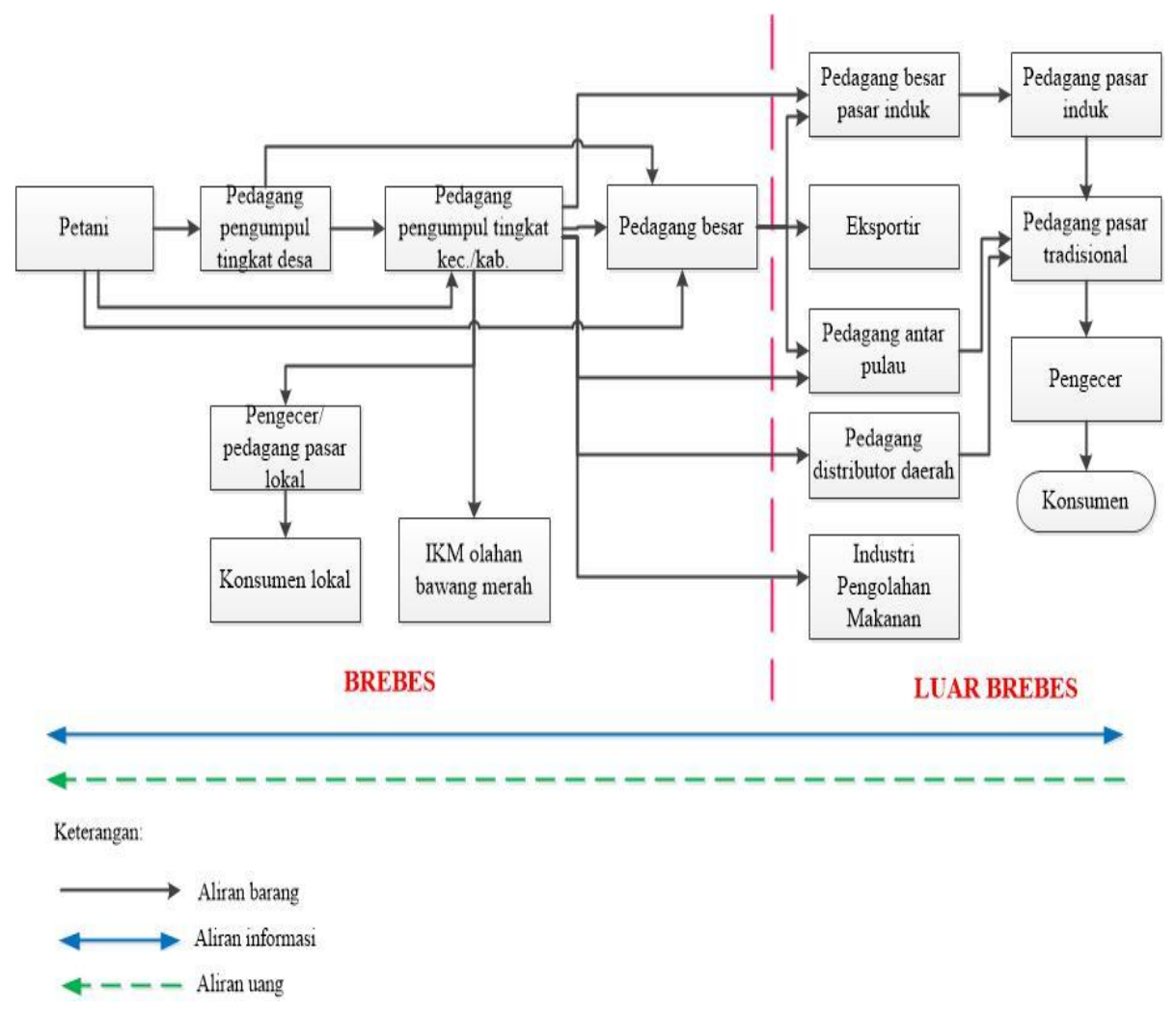

Gambar 2. Struktur rantai pasok bawang merah dari Kabupaten Brebes ke berbagai tujuan pasar 
Dalam rantai pasok bawang merah di Kabupaten Brebes, pelaku rantai pasok tidak melakukan koordinasi baik secara vertikal (berbeda level) maupun horizontal (sesama level) mengenai perencanaan produksi, distribusi maupun perencanaan pemasaran. Selain itu, tidak ditemukan adanya kemitraan dan kolaborasi antar pelaku rantai pasok maupun antar organisasi. Hal ini menunjukkan bahwa integrasi dalam rantai pasok bawang merah di Kabupaten Brebes masih lemahProses kerjasama dapat ditemukan diantara pelaku rantai pasok dalam aktivitas pengangkutan/pengiriman bawang merah dari Brebes menuju pasar induk. Dalam mengirim bawang merah ke berbagai daerah di Indonesia, pedagang yang memiliki modal cukup besar dapat mengirimnya sendiri sedangkan pelaku rantai pasok yang memiliki modal sedikit dapat bergabung dengan pedagang lainnya.

Pola kemitraan dapat ditemukan pada industri makanan skala besar dengan para pemasok (supplier) bawang merah yang berperan sebagai pedagang pengumpul. Pada awalnya kemitraan tersebut dilakukan dengan KUD (Koperasi Unit Desa) Wanasari, namun kemitraan ini tidak berjalan dengan baik. Hal ini terjadi karena kesepakatan mengenai harga bawang merah tidak terbentuk.

Sumber daya fisik yang menunjang rantai pasok bawang merah di Kabupaten Brebes meliputi lahan budidaya, tempat penampungan air (embung), infrastruktur/sarana prasarana, sarana transportasi pengangkutan, lapak-lapak pengeringan, pasar khusus untuk jual beli bawang merah dan gudang penyimpanan. Terdapat sembilan gudang penyimpanan yang dibangun oleh pemerintah untuk kepentingan penyimpanan komoditas pertanian termasuk bawang merah, namun kondisi saat ini gudang tersebut tidak berfungsi sebagaimana mestinya karena tidak dikelola dengan baik. Hanya satu gudang yang berfungsi yaitu gudang yang terdapat di Sub Terminal Agribisnis (STA) Larangan.

Kemampuan pelaku rantai pasok dalam pengusahaan (produksi, distribusi, pemasaran) bawang merah dilakukan atas dasar kemampuan permodalan. Pelaku rantai pasok terutama petani, akan memasok bawang merah sesuai modal yang dimiliki. Pelaku rantai pasok yang memiliki modal besar mampu memenuhi permintaan pasar.

\section{Pengukuran Kinerja Rantai Pasok Bawang Merah}

Hasil pembobotan metrik kinerja dan pengukuran kinerja pelaku rantai pasok secara lebih rinci dapat dilihat pada Tabel 2, 3, dan 4 sedangkan rekapitulasi nilai kinerja pelaku rantai pasok bawang merah di Kabupaten Brebes ditunjukkan pada Tabel 5.

Tabel 2. Hasil pembobotan dan penilaian metrik kinerja petani

\begin{tabular}{|c|c|c|c|c|c|c|}
\hline \multirow{2}{*}{ Nomor Level } & \multirow{2}{*}{ Metrik } & \multirow{2}{*}{ Bobot } & \multicolumn{2}{|c|}{ Skor } & \multicolumn{2}{|c|}{ Skor Terbobot } \\
\hline & & & in & off & in & off \\
\hline \multicolumn{7}{|c|}{ RELIABILITAS } \\
\hline RL.1.1 & Pemenuhan pesanan sempurna & 0,18 & & & 4,00 & 3,25 \\
\hline RL.2.1 & Pesanan terkirim secara utuh & 0,75 & & & 4,14 & 3,29 \\
\hline RL.3.1 & Ketepatan jenis barang yang terkirim & 0,57 & 4,00 & 4,00 & & \\
\hline RL.3.2 & Ketepatan jumlah yang terkirim & 0,43 & 4,33 & 2,33 & & \\
\hline RL.2.2 & Kondisi sempurna & 0,25 & & & 3,56 & 3,13 \\
\hline RL.3.3 & $\%$ Bebas kerusakan/kehilangan & 0,31 & 3,33 & 2,67 & & \\
\hline RL.3.4 & $\%$ Kesesuaian dengan standar mutu & 0,70 & 3,67 & 3,33 & & \\
\hline \multicolumn{7}{|c|}{ RESPONSIVITAS } \\
\hline RS.1.1 & Waktu siklus pemenuhan pesanan & 0,13 & & & 3,37 & 3,46 \\
\hline RS.2.1 & Waktu siklus pengadaan & 0,35 & & & 3,20 & 3,47 \\
\hline RS.3.1 & Waktu persiapan lahan & 0,42 & 3,00 & 3,67 & & \\
\hline RS.3.2 & Waktu persiapan saprotan & 0,20 & 4,00 & 4,00 & & \\
\hline RS.3.3 & Waktu pembibitan & 0,39 & 3,00 & 3,00 & & \\
\hline RS.2.2 & Waktu siklus produksi & 0,65 & & & 3,47 & 3,45 \\
\hline RS.3.4 & Waktu budidaya & 0,53 & 3,00 & 3,33 & & \\
\hline RS.3.5 & Waktu panen & 0,17 & 4,00 & 4,00 & & \\
\hline RS.3.6 & Waktu pascapanen & 0,30 & 4,00 & 3,33 & & \\
\hline \multicolumn{7}{|l|}{ BIAYA } \\
\hline BI.1.1 & Total biaya pelayanan & 0,31 & & & 3,53 & 3,33 \\
\hline BI.2.1 & Biaya pengadaan & 0,33 & & & 3,58 & 3,41 \\
\hline BI.3.1 & Biaya saprotan & 0,26 & 3,33 & 3,33 & & \\
\hline BI.3.2 & Biaya pembibitan & 0,51 & 3,67 & 3,33 & & \\
\hline BI.3.3 & Biaya lahan & 0,23 & 3,67 & 3,67 & & \\
\hline BI.2.2 & Biaya penanganan/ produksi & 0,75 & & & 3,14 & 2,95 \\
\hline BI.3.4 & Biaya proses budidaya & 0,57 & 3,00 & 2,67 & & \\
\hline BI.3.5 & Biaya panen dan pascapanen & 0,43 & 3,33 & 3,33 & & \\
\hline \multicolumn{7}{|l|}{ ASET } \\
\hline AS.1.1 & Waktu siklus kas & 0,37 & & & 3,00 & 3,00 \\
\hline AS. 2.1 & Rentang pembayaran utang & 0,16 & 3,00 & 3,00 & & \\
\hline \multirow[t]{2}{*}{ AS.2.2 } & Rentang pembayaran piutang & 0,84 & 3,00 & 3,00 & & \\
\hline & TOTAL KINERJA & & & & 3,39 & 3,20 \\
\hline
\end{tabular}


Tabel 3. Hasil pembobotan dan penilaian metrik kinerja pedagang pengumpul

\begin{tabular}{|c|c|c|c|c|c|c|}
\hline \multirow{2}{*}{$\begin{array}{c}\text { Nomor } \\
\text { Level }\end{array}$} & \multirow{2}{*}{ Metrik } & \multirow{2}{*}{ Bobot } & \multicolumn{2}{|c|}{ Skor } & \multicolumn{2}{|c|}{ Skor Terbobot } \\
\hline & & & in & off & in & off \\
\hline \multicolumn{7}{|c|}{ RELIABILITAS } \\
\hline RL.1.1 & Pemenuhan pesanan sempurna & 0,13 & & & 4,12 & 3,62 \\
\hline RL.2.1 & Pesanan terkirim secara utuh & 0,40 & & & 4,24 & 3,65 \\
\hline RL.3.1 & Ketepatan jenis barang yang terkirim & 0,65 & 4,00 & 4,00 & & \\
\hline RL.3.2 & Ketepatan jumlah yang terkirim & 0,35 & 4,67 & 3,00 & & \\
\hline RL.2.2 & Kinerja pengiriman & 0,24 & & & 4,24 & 4,12 \\
\hline RL.3.3 & Ketepatan lokasi tujuan pengiriman & 0,35 & 4,67 & 4,33 & & \\
\hline RL.3.4 & Ketepatan waktu pengiriman & 0,65 & 4,00 & 4,00 & & \\
\hline RL.2.3 & Kondisi sempurna & 0,36 & & & 3,92 & 3,25 \\
\hline RL.3.5 & \% Bebas kerusakan/kehilangan & 0,25 & 3,67 & 3,00 & & \\
\hline RL.3.6 & $\%$ Kesesuaian dengan standar mutu & 0,75 & 4,00 & 3,33 & & \\
\hline \multicolumn{7}{|c|}{ RESPONSIVITAS } \\
\hline RS.1.1 & Waktu siklus pemenuhan pesanan & 0,10 & & & 3,67 & 3,33 \\
\hline RS.2.1 & Waktu siklus pengadaan & 0,44 & & & 3,43 & 3,00 \\
\hline RS.3.1 & Waktu pemilihan pemasok & 0,43 & 4,00 & 3,00 & & \\
\hline RS.3.2 & Waktu siklus penerimaan barang & 0,57 & 3,00 & 3,00 & & \\
\hline RS.2.2 & Waktu siklus produksi & 0,29 & & & 3,74 & 3,47 \\
\hline RS.3.3 & Waktu panen dan pascapanen & 0,79 & 3,67 & 3,33 & & \\
\hline RS.3.4 & Waktu pengemasan & 0,21 & 4,00 & 4,00 & & \\
\hline RS.2.3 & Waktu pengiriman & 0,27 & & & 4,00 & 3,72 \\
\hline RS.3.5 & Waktu muatan ke dalam kendaraan & 0,17 & 4,00 & 4,00 & & \\
\hline RS.3.6 & Lama pengiriman & 0,83 & 4,00 & 3,67 & & \\
\hline \multicolumn{7}{|c|}{ FLEKSIBILITAS } \\
\hline FL.1.1 & Fleksibilitas rantai pasok atas & 0,10 & & & 4,00 & 2,92 \\
\hline FL.2.1 & Fleksibilitas peningkatan pengadaan & 0,25 & 4,00 & 2,67 & & \\
\hline FL.2.2 & Fleksibilitas pengiriman & 0,75 & 4,00 & 3,00 & & \\
\hline \multicolumn{7}{|l|}{ BIAYA } \\
\hline BI.1.1 & Total biaya pelayanan & 0,26 & & & 3,70 & 3,14 \\
\hline \multirow{2}{*}{$\begin{array}{c}\text { Nomor } \\
\text { Level }\end{array}$} & \multirow{2}{*}{ Metrik } & \multirow{2}{*}{ Bobot } & \multicolumn{2}{|c|}{ Skor } & \multicolumn{2}{|c|}{ Skor Terbobot } \\
\hline & & & in & off & in & off \\
\hline BI.2.1 & Biaya pengadaan & 0,56 & & & 4,00 & 3,00 \\
\hline BI.3.1 & Biaya pembelian barang & 1,00 & 4,00 & 3,00 & & \\
\hline BI.2.2 & Biaya penanganan/ produksi & 0,31 & & & 3,46 & 3,46 \\
\hline BI.3.2 & Biaya pengemasan & 0,12 & 4,00 & 4,00 & & \\
\hline BI.3.3 & Biaya sewa lapak penjemuran & 0,34 & 4,00 & 4,00 & & \\
\hline BI.3.4 & Biaya panen dan pascapanen & 0,54 & 3,00 & 3,00 & & \\
\hline BI.2.3 & Biaya pengiriman & 0,14 & & & 3,00 & 3,00 \\
\hline BI.3.5 & Biaya pengangkutan & 1,00 & 3,00 & 3,00 & & \\
\hline$\overline{\text { ASET }}$ & & & & & & \\
\hline AS. 1 & Waktu siklus kas & 0,42 & & & 3,00 & 3,00 \\
\hline AS.2.1 & Rentang pembayaran utang & 0,17 & 3,00 & 3,00 & & \\
\hline AS.2.2 & Rentang pembayaran piutang & 0,83 & 3,00 & 3,00 & & \\
\hline & TOTAL KINERJA & & & & 3,49 & 3,14 \\
\hline
\end{tabular}

Tabel 4. Hasil pembobotan dan penilaian metrik kinerja pedagang Besar

\begin{tabular}{|c|c|c|c|c|c|c|}
\hline \multirow{2}{*}{ Nomor Level } & \multirow{2}{*}{ Metrik } & \multirow{2}{*}{ Bobot } & \multicolumn{2}{|c|}{ Skor } & \multicolumn{2}{|c|}{ Skor terbobot } \\
\hline & & & in & of & in & $o f$ \\
\hline \multicolumn{7}{|c|}{ RELIABILITAS } \\
\hline RL.1.1 & Pemenuhan pesanan sempurna & 0,16 & & & 4,03 & 3,59 \\
\hline RL.2.1 & Pesanan terkirim secara utuh & 0,39 & & & 4,08 & 3,77 \\
\hline RL.3.1 & Ketepatan jenis barang yang terkirim & 0,77 & 4,00 & 4,00 & & \\
\hline RL.3.2 & Ketepatan jumlah yang terkirim & 0,23 & 4,33 & 3,00 & & \\
\hline RL.2.2 & Kinerja pengiriman & 0,22 & & & 4,00 & 3,35 \\
\hline RL.3.3 & Ketepatan lokasi tujuan pengiriman & 0,35 & 4,00 & 4,00 & & \\
\hline RL.3.4 & Ketepatan waktu pengiriman & 0,65 & 4,00 & 3,00 & & \\
\hline RL.2.3 & Kondisi sempurna & 0,39 & & & 4,00 & 3,55 \\
\hline RL.3.5 & $\%$ Bebas kerusakan/ kehilangan & 0,17 & 4,00 & 3,00 & & \\
\hline RL.3.6 & $\%$ Kesesuaian dengan standar mutu & 0,83 & 4,00 & 3,67 & & \\
\hline \multicolumn{7}{|c|}{ RESPONSIVITAS } \\
\hline RS.1.1 & Waktu siklus pemenuhan pesanan & 0,16 & & & 3,86 & 3,38 \\
\hline RS.2.1 & Waktu siklus pengadaan & 0,30 & & & 3,88 & 3,00 \\
\hline RS.3.1 & Waktu pemilihan pemasok & 0,35 & 3,67 & 3,00 & & \\
\hline RS.3.2 & Waktu siklus penerimaan barang & 0,65 & 4,00 & 3,00 & & \\
\hline RS.2.2 & Waktu siklus produksi & 0,40 & & & 3,74 & 3,21 \\
\hline
\end{tabular}




\begin{tabular}{|c|c|c|c|c|c|c|}
\hline \multirow{2}{*}{ Nomor Level } & \multirow{2}{*}{ Metrik } & \multirow{2}{*}{ Bobot } & \multicolumn{2}{|c|}{ Skor } & \multicolumn{2}{|c|}{ Skor terbobot } \\
\hline & & & in & of & in & of \\
\hline RS.3.3 & Waktu panen dan pascapanen & 0,79 & 3,67 & 3,00 & & \\
\hline RS.3.4 & Waktu pengemasan & 0,21 & 4,00 & 4,00 & & \\
\hline RS.2.3 & Waktu pengiriman & 0,30 & & & 4,00 & 4,00 \\
\hline RS.3.5 & Waktu loading ke truk & 0,29 & 4,00 & 4,00 & & \\
\hline RS.3.6 & Lama pengiriman & 0,71 & 4,00 & 4,00 & & \\
\hline \multicolumn{7}{|c|}{ FLEKSIBILITAS } \\
\hline FL.1.1 & Fleksibilitas rantai pasok atas & 0,12 & & & 4,00 & 3,00 \\
\hline FL.2.1 & Fleksibilitas peningkatan pengadaan & 0,21 & 4,00 & 3,00 & & \\
\hline FL. 2.2 & Fleksibilitas pengiriman & 0,79 & 4,00 & 3,00 & & \\
\hline \multicolumn{7}{|l|}{ BIAYA } \\
\hline BI.1.1 & Total biaya pelayanan & 0,23 & & & 3,38 & 3,08 \\
\hline BI.2.1 & Biaya pengadaan & 0,39 & & & 3,75 & 3,00 \\
\hline BI.3.1 & Biaya Pembelian barang & 0,75 & 3,67 & 3,00 & & \\
\hline BI.3.2 & Biaya penyimpanan & 0,25 & 4,00 & 3,00 & & \\
\hline BI.2.2 & Biaya penanganan/ produksi & 0,39 & & & 3,21 & 3,21 \\
\hline BI.3.3 & Biaya panen dan pascapanen & 0,79 & 3,00 & 3,00 & & \\
\hline BI.3.4 & Biaya pengemasan & 0,21 & 4,00 & 4,00 & & \\
\hline BI.2.3 & Biaya pengiriman & 0,22 & & & 3,00 & 3,00 \\
\hline BI.3.5 & Biaya pengangkutan & 1,00 & 3,00 & 3,67 & & \\
\hline \multicolumn{7}{|l|}{ ASET } \\
\hline AS.1.1 & Waktu siklus kas & 0,33 & & & 4,00 & 4,00 \\
\hline AS.2.1 & Rentang pembayaran utang & 0,29 & 4,00 & 4,00 & & \\
\hline AS.2.2 & Rentang pembayaran piutang & 0,71 & 4,00 & 4,00 & & \\
\hline & TOTAL KINERJA & & & & 3,84 & 3,50 \\
\hline
\end{tabular}

Tabel 5. Rekapitulasi nilai kinerja pelaku rantai pasok bawang merah di Kabupaten Brebes

\begin{tabular}{|c|c|c|c|c|c|c|c|c|c|}
\hline \multirow{3}{*}{ Atribut } & \multirow{3}{*}{ Metrik Level 1} & \multicolumn{6}{|c|}{ Kinerja pelaku rantai pasok } & \multirow{2}{*}{\multicolumn{2}{|c|}{$\begin{array}{c}\text { Kinerja } \\
\text { rantai }\end{array}$}} \\
\hline & & \multicolumn{2}{|c|}{ Petani } & \multicolumn{2}{|c|}{$\begin{array}{c}\text { Pedagang } \\
\text { pengumpul }\end{array}$} & \multicolumn{2}{|c|}{$\begin{array}{c}\text { Pedagang } \\
\text { besar }\end{array}$} & & \\
\hline & & in & off & in & off & in & off & in & off \\
\hline Reliabilitas & Pemenuhan pesanan sempurna & 4,00 & 3,25 & 4,12 & 3,62 & 4,03 & 3,59 & 4,05 & 3,49 \\
\hline Responsivitas & Waktu siklus pemenuhan pesanan & 3,37 & 3,46 & 3,67 & 3,33 & 3,86 & 3,38 & 3,63 & 3,39 \\
\hline Fleksibilitas & Fleksibilitas rantai pasok atas & - & - & 4,00 & 2,92 & 4,00 & 3,00 & 4,00 & 2,96 \\
\hline Biaya & Total biaya pelayanan & 3,53 & 3,33 & 3,70 & 3,14 & 3,38 & 3,08 & 3,54 & 3,18 \\
\hline Aset & Waktu siklus kas & 3,00 & 3,00 & 3,00 & 3,00 & 4,00 & 4,00 & 3,33 & 3,33 \\
\hline & Total Nilai & 3.39 & 3,20 & 3,49 & 3,14 & 3,84 & 3,50 & 3,57 & 3,28 \\
\hline
\end{tabular}

Keterangan: $i n=$ musim panen, off = luar musim panen

Berdasarkan Tabel 2, 3, dan 4 dapat diketahui bahwa metrik kinerja level satu yaitu waktu siklus kas (pada atribut manajemen aset) memiliki nilai bobot tertinggi pada semua pelaku rantai pasok (pedagang besar, pedagang pengumpul, dan petani). Posisi kedua ditempati oleh metrik total biaya pelayanan (atribut biaya). Waktu siklus kas (pada atribut manajemen aset) menjadi aspek yang sangat penting dan sangat dipertimbangkan karena para pelaku rantai pasok membutuhkan uang sebagai modal dalam melakukan aktivitasnya. Kebutuhan akan uang ini sangat mendesak karena modal yang mereka miliki sangat minim sehingga kemampuan mengelola arus kas (cash flow) sangat penting dan dibutuhkan. Metrik total biaya pelayanan (pada atribut biaya rantai pasok) menduduki peringkat kedua dalam tingkat kepentingan rantai pasok bawang merah disebabkan total biaya pelayanan adalah salah satu faktor penentu harga bawang merah. Metrik total biaya pelayanan mencakup biaya pengadaan (bahan baku), biaya produksi, dan biaya pengiriman.
Hasil pengukuran pada tingkat reliabilitas menunjukkan nilai yang tinggi saat in season dan rendah saat off season. Ketersediaan bawang merah yang melimpah pada saat in season menyebabkan kinerja reliabilitas pelaku rantai pasok meningkat. Kondisi ini juga menjadi alasan tingginya nilai kinerja responsivitas dan fleksibilitas pada pedagang pengumpul dan pedagang besar. Kinerja responsivitas petani saat off season umumnya lebih tinggi dibanding saat in season kecuali metrik waktu untuk pascapanen (Tabel 2). Hal ini disebabkan saat off season terdapat air hujan yang membantu percepatan proses persiapan lahan dan proses budidaya. Sebaliknya waktu untuk pascapanen memiliki kinerja yang rendah karena saat musim penghujan adalah kondisi sedikit terdapat panas yang berguna untuk mengeringkan bawang merah. Untuk persiapan saprotan tidak membutuhkan waktu yang lama karena saprotan dapat dibeli dan diperoleh secara langsung serta dapat disimpan dalam jangka waktu yang lama. Petani tidak memiliki nilai pada metrik fleksibilitas rantai pasok atas karena petani tidak mampu memenuhi 
permintaan dari konsumen jika terjadi peningkatan kapasitas permintaan yang tidak terencana (mendadak).

Atribut manajemen aset yang digambarkan oleh metrik waktu siklus kas menunjukkan kemampuan pelaku rantai pasok dalam mengatur keuangannya yang seimbang antara konsumen, pemasok dan internalnya. Kinerja manajemen aset pedagang besar menunjukkan nilai yang lebih tinggi dibandingkan petani dan pedagang pengumpul. Hal ini terjadi karena pedagang besar memiliki posisi tawar (bargaining position) yang kuat baik di mata pemasok maupun konsumen. Posisi tawaryang dimiliki pedagang besar tidak terlepas dari kepemilikan modal yang besar serta kekuatan jaringan yang telah dibentuk.

\section{Perumusan Upaya Peningkatan Kinerja Rantai Pasok Bawang Merah}

Analisis Kesenjangan

Dalam upaya peningkatan kinerja rantai pasok bawang merah, terdapat istilah kinerja aktual (kinerja saat ini) dan kinerja yang menjadi target (ukuran tujuan peningkatan). Perbedaan nilai pada dua kondisi tersebut menggambarkan adanya kesenjangan (gap) antara kinerja aktual dengan kinerja target. Nilai gap merupakan indikator mengenai besar tidaknya upaya perbaikan yang perlu dilakukan pada proses-proses di dalam rantai pasok terkait dengan metrik kinerja yang digunakan. Selain itu, gap kinerja ini dapat dijadikan bahan evaluasi untuk merencanakan proses perbaikan kinerja sehingga peningkatan kinerja di masa mendatang dapat dicapai. Berdasarkan analisis kesenjangan pada kinerja pelaku rantai pasok bawang merah di Kabupaten Brebes, metrik yang memiliki gap antara kondisi saat ini dengan kondisi yang diharapkan (target yang ingin dicapai) dapat dilihat pada Tabel 6.

\section{Analisis Masalah Rantai Pasok Bawang Merah}

Berdasarkan hasil analisis kondisi dan pengukuran kinerja rantai pasok serta analisis kesenjangan, terdapat beberapa permasalahan dalam rantai pasok bawang merah di Kabupaten Brebes. Hasil analisis melalui diagram fishbone dapat dilihat pada Gambar 3. Diagram fishbone ini ditetapkan sebagai diagram fishbone induk. Kemudian, dari masing-masing faktor penyebab diagram fishbone induk, dipecah kembali ke dalam diagram fishbone anak. Kendala yang dihadapi ini menyebabkan rantai pasok bawang merah di Kabupaten Brebes kurang efektif dan efisien.

\section{Ketersediaan Bawang Merah Rendah Terutama Saat Off Season}

Penyebab ketersediaan bawang merah rendah terutama saat off season dapat dilihat pada Gambar 4. Sebagian besar petani di Kabupaten Brebes tidak menggunakan SOP budidaya (Standar Operational Procedure). Hal ini disebabkan adanya sikap tertutup dari masyarakat yang enggan menggunakan teknologi baru dalam budidaya bawang merah. Petani lebih memilih teknik budidaya sendiri berdasarkan pengalaman sebelumnya.

Tabel 6. Metrik kinerja yang memiliki gap

\begin{tabular}{|c|c|c|c|}
\hline Atribut & Petani & Pedagang pengumpul & Pedagang besar \\
\hline \multirow{4}{*}{ 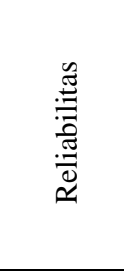 } & Ketepatan jumlah barang & Ketepatan jumlah yang terkirim & Ketepatan jumlah yang terkirim \\
\hline & $\begin{array}{l}\% \text { Bebas kerusakan/ } \\
\text { kehilangan }\end{array}$ & Ketepatan waktu pengiriman & Ketepatan waktu pengiriman \\
\hline & $\begin{array}{l}\% \text { Kesesuaian dengan } \\
\text { standar mutu }\end{array}$ & $\%$ Bebas kerusakan/ kehilangan & \% Bebas kerusakan/ kehilangan \\
\hline & & $\%$ Kesesuaian dengan standar mutu & $\begin{array}{l}\% \text { Kesesuaian dengan standar } \\
\text { mutu }\end{array}$ \\
\hline \multirow{3}{*}{ 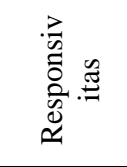 } & Waktu persiapan lahan & Waktu pemilihan pemasok & Waktu pemilihan pemasok \\
\hline & Waktu pembibitan & Waktu siklus penerimaan barang & Waktu siklus penerimaan barang \\
\hline & $\begin{array}{l}\text { Waktu budidaya } \\
\text { Waktu pascapanen }\end{array}$ & Waktu panen dan pascapanen & Waktu panen dan pascapanen \\
\hline \multirow{2}{*}{ 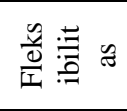 } & & Fleksibilitas peningkatan pengadaan & $\begin{array}{l}\text { Fleksibilitas peningkatan } \\
\text { pengadaan }\end{array}$ \\
\hline & & Fleksibilitas pengiriman & Fleksibilitas pengiriman \\
\hline \multirow{5}{*}{$\stackrel{\frac{\pi}{\pi}}{\stackrel{\pi}{\infty}}$} & Biaya saprotan & Biaya pembelian barang & Biaya pembelian barang \\
\hline & Biaya pembibitan & Biaya panen dan pascapanen & Biaya penyimpanan \\
\hline & Biaya sewa lahan & Biaya pengangkutan & Biaya panen dan pascapanen \\
\hline & Biaya proses budidaya & & Biaya pengangkutan \\
\hline & Biaya panen dan pascapanen & & \\
\hline \multirow{2}{*}{ 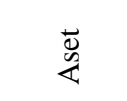 } & Rentang pembayaran utang & Rentang pembayaran utang & \\
\hline & Rentang pembayaran piutang & Rentang pembayaran piutang & \\
\hline
\end{tabular}




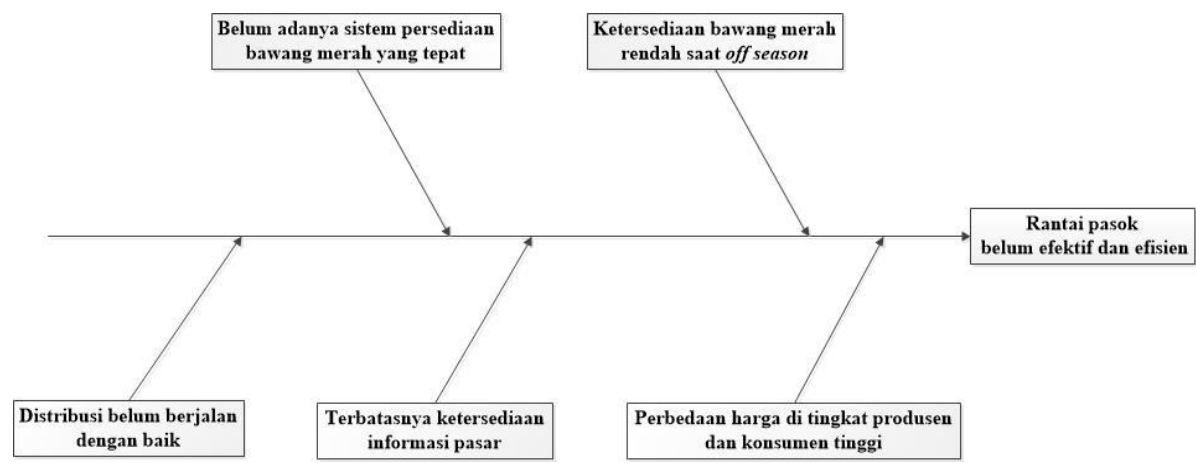

Gambar 3. Diagram fishbone (induk) rantai pasok belum efektif dan efisien

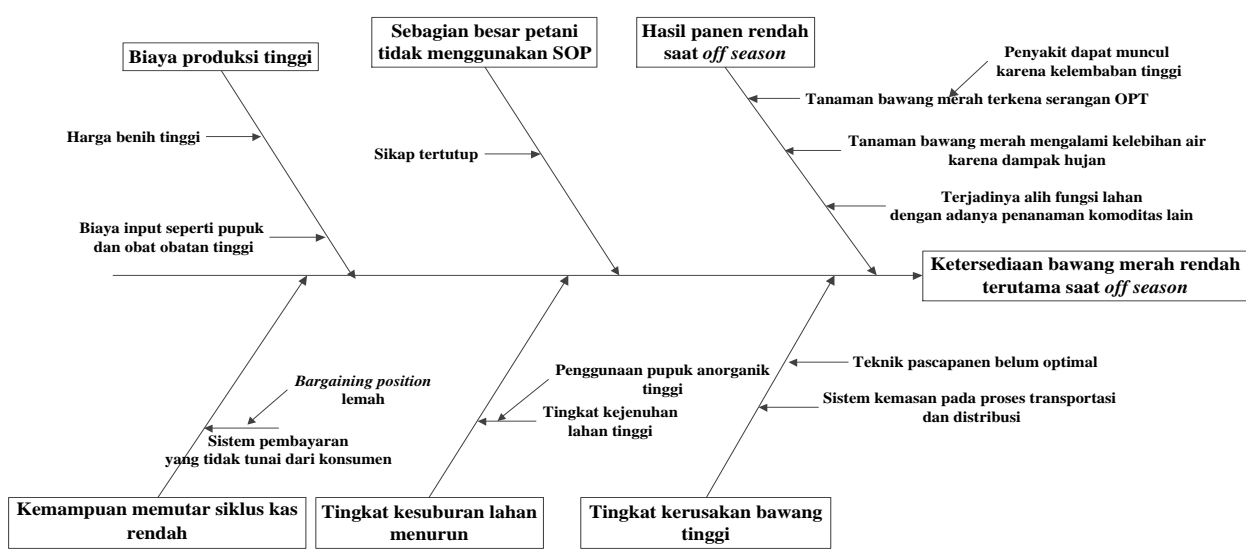

Gambar 4. Diagram fishbone ketersediaan bawang merah rendah terutama saat off season

Kerusakan pada bawang merah dapat berupa keropos, berjamur, berakar, dan lainnya. Kerusakan tersebut dapat diakibatkan proses penyimpanan, pengeringan dan sistem kemasan pada proses transportasi dan distribusi. Hal ini disebabkan oleh teknik pascapanen yang masih konvensional. Penggunaan lahan untuk penanaman bawang merah yang dilakukan secara terus menerus dapat mengakibatkan tingkat kesuburan menurun yang diindikasikan karena tingkat kejenuhan yang tinggi.

Hal ini disebabkan oleh pemakaian pupuk anorganik yang tinggi. Umumnya pelaku rantai pasok bawang merah memiliki kemampuan yang rendah dalam memutar siklus kasnya. Hal ini disebabkan sistem pembayaran yang tidak tunai oleh konsumen. Kejadian ini umumnya dialami oleh sebagian besar petani. Penyebabnya adalah petani memiliki bargaining position yang lemah.

Biaya produksi seperti biaya bahan baku tinggi disebabkan kemampuan permodalan yang rendah, subsidi belum merata dan tingginya harga benih. Harga benih yang tinggi disebabkan beberapa faktor diantaranya terjadi penyusutan selama penyimpanan, proses penyimpanan memakan tempat yang luas dan waktu yang lama, proses penyimpanan menggunakan bahan pengawet dan ketergantungan pada harga bawang merah yang berfluktuasi (Gambar 5). Karakteristik bawang merah yang cepat busuk (perishable) dan memakan tempat (bulky) dapat menyebabkan biaya untuk proses pembibitan tinggi sehingga harga benih menjadi mahal.

\section{Belum Adanya Sistem Persediaan yang Tepat}

Persediaan diperlukan untuk menyediakan produk musiman sepanjang tahun. Untuk memenuhi kebutuhan konsumen dalam jumlah tertentu, produk musiman seperti bawang merah dapat disimpan dalam jangka waktu tertentu dengan menerapkan sistem persediaan yang tepat. Hal ini bermanfaat untuk menekan terjadinya fluktuasi harga bawang merah. Kondisi saat ini belum terbentuk model sistem persediaan bawang merah baik di tingkat pusat maupun daerah, baik pihak pemerintah maupun swasta. Penyebabnya dapat dilihat pada Gambar 6.

Teknik penyimpanan yang diterapkan saat ini masih konvensional sehingga tidak mampu menyimpan bawang merah dalam jangka waktu yang lama. Teknologi penyimpanan bawang merah sebenarnya telah banyak diteliti oleh lembaga penelitian maupun institusi pendidikan. Namun, dalam prakteknya, penemuan tersebut belum dapat diaplikasikan karena terkendala beberapa hal diantaranya 1) aspek ekonomi (mahalnya teknologi), 2) kesadaran masyarakat akan penerapan teknologi masih minim, 3) masyarakat masih mempertimbangkan tingkat kepraktisan dari sebuah teknologi, dan 4) kurangnya sosialisasi ataupun bimbingan mengenai teknologi tepat guna. 


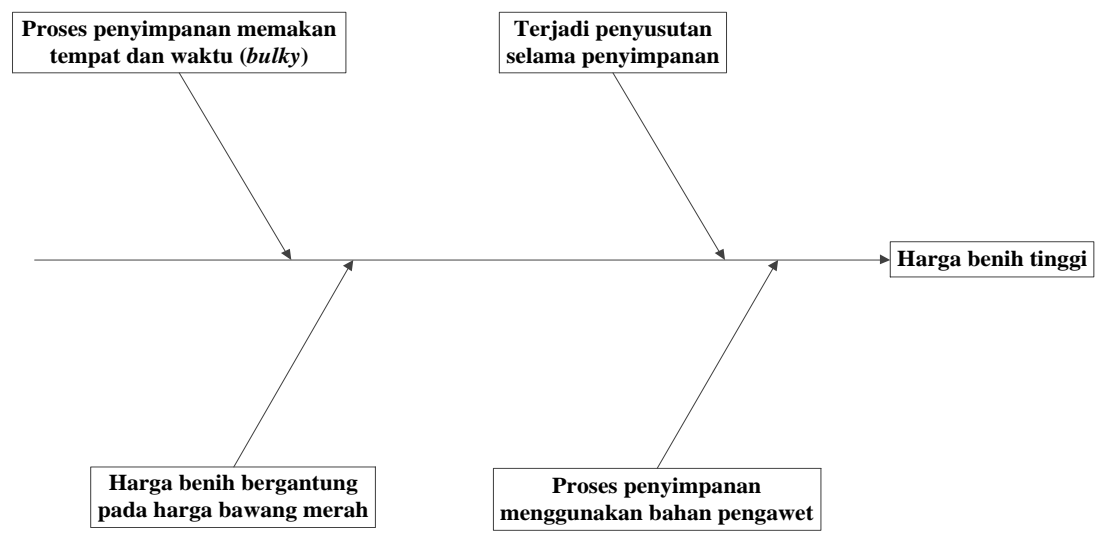

Gambar 5. Diagram fishbone harga benih yang tinggi

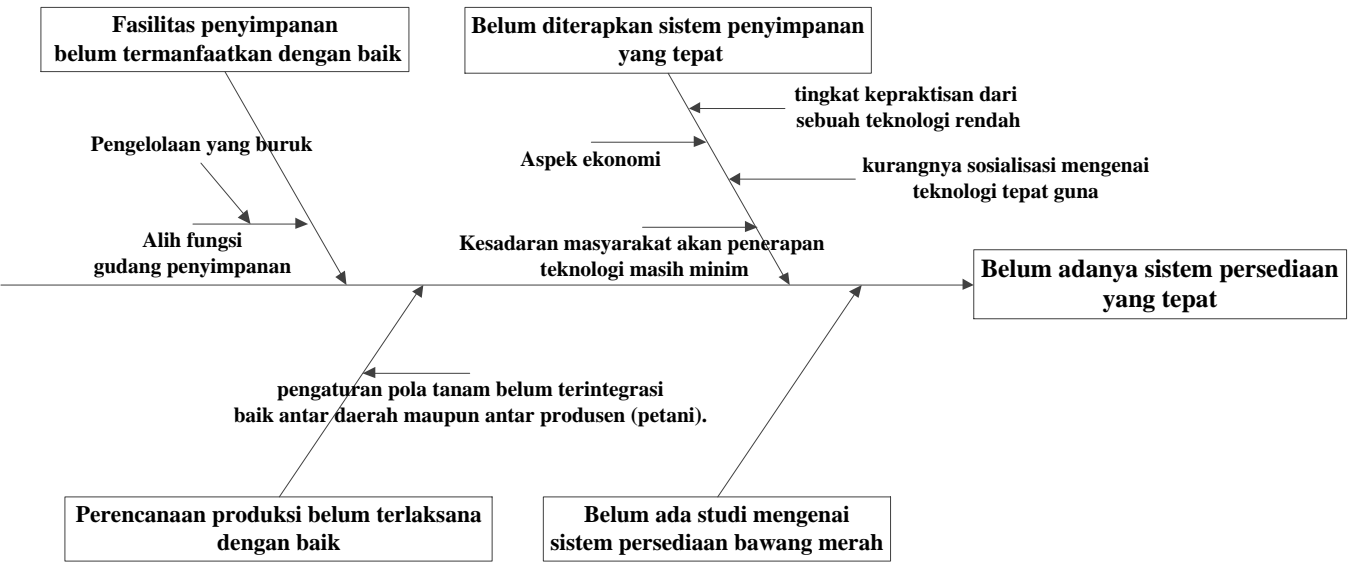

Gambar 6. Diagram fishbone penyebab belum adanya sistem persediaan yang tepat

Bawang merah umumnya ditanam menjelang musim kemarau. Dewasa ini telah ada varietas tertentu yang dapat dibudidayakan di luar musim (off season). Hal ini berdampak positif terhadap ketersediaan dan kesinambungan bawang merah di pasaran. Untuk memenuhi kebutuhan bawang merah yang cenderung stabil pada hari-hari biasa dan mengantisipasi kenaikan permintaan pada waktu tertentu, perlu dilakukan penyesuaian perencanaan pola tanam dan produksi yang mengikuti keseimbangan supply-demand.

Kenyataannya di lapangan, perencanaan produksi melalui pengaturan pola tanam belum terintegrasi baik antar daerah maupun antar produsen (petani). Pola tanam yang telah dilakukan belum mempertimbangkan keseimbangan supply-demand. Sekitar $46 \%$ petani menggunakan pola tanam padibawang merah-bawang merah (dalam satu tahun) dari sembilan pola tanam yang ada (Winarso, 2003). Hal ini berdampak pada puncak panen yang terjadi pada bulan-bulan tertentu sehingga fluktuasi harga tidak bisa dihindari.

Pengaturan pola tanam belum terintegrasi dengan baik disebabkan oleh kecenderungan petani yang ingin mengambil keuntungan terbesar dengan pola tanam tertentu. Hal ini dilakukan untuk menghindari risiko gagal panen yang disebabkan oleh adanya anomali iklim seperti musim hujan yang berkepanjangan sehingga menyebabkan munculnya hama maupun penyakit ataupun musim kering dengan tingkat kekeringan yang sangat tinggi sehingga mengalami kekurangan pasokan air untuk tanaman.

\section{Perbedaan Harga di Tingkat Produsen Dengan Harga di Tingkat Konsumen Sangat Jauh}

Perbedaan harga di tingkat pasar produsen dengan harga di tingkat pasar konsumen telah membentuk margin pemasaran yang cukup dinamis. Sebagian besar harga bawang merah masih dinikmati oleh para pedagang. Jauhnya perbedaan harga di tingkat produsen (petani) dengan harga di tingkat kosumen mencerminkan bahwa transformasi harga cenderung hanya sampai ditangan para pelaku pasar (pedagang) (Winarso, 2003). Berdasarkan penelitian yang dilakukan oleh Rosyadi (2014), margin pemasaran bawang merah pada petani dengan tujuan pemasaran pedagang pengecer memiliki nilai yang tinggi hingga mencapai 50-60\%. Nurasa dan Darwis (2007) juga menyebutkan bahwa 
margin pemasaran terbesar diperoleh dengan tujuan pedagang pengecer dan pasar modern. Penyebab perbedaan harga di tingkat produsen dengan harga di tingkat konsumen selengkapnya dapat dilihat pada Gambar 7.

Pengusahaan bawang merah di Kabupaten Brebes melibatkan banyak pelaku seperti calo (pedagang pengumpul desa), jasa sortasi/ pembersihan, pedagang pengumpul kecamatan/ kabupaten, kurir (jasa antar barang), jasa angkutan (ekspedisi), pedagang besar, pedagang pasar tradisional dan pengecer. Setiap pelaku tersebut menyebabkan adanya penambahan biaya pada harga jual bawang merah. Oleh sebab itu, harga bawang merah menjadi sangat tinggi. Rentang jarak antara produsen dengan konsumen akhir yang jauh baik dari segi fisik maupun geografi membutuhkan jasa perantara sehingga menyebabkan rantai pemasaran semakin panjang.

Sifat bawang merah yang bulky dan cepat rusak/ membusuk serta adanya kebutuhan ekonomi rumah tangga yang mendesak menyebabkan petani produsen tidak memiliki posisi tawar yang kuat. Apalagi jika penjualan bawang merah dilakukan dengan sistem tebasan. Hal-hal tersebut menyebabkan semakin lebarnya jarak harga bawang merah di tingkat produsen dengan harga di tingkat konsumen (Winarso, 2003).

\section{$\underline{\text { Terbatasnya Ketersediaan Informasi Pasar }}$}

Salah satu faktor yang mempengaruhi kelancaran rantai pasok bawang merah adalah aliran informasi yang tepat dan akurat baik dari downstream ke upstream atau sebaliknya. Informasi pasar merupakan satu syarat penting dalam pengembangan pemasaran sesuai dinamika perubahan pasar yang sangat cepat. Karenanya kebutuhan dan tuntutan akan informasi pasar semakin meningkat yaitu informasi pasar yang berkualitas, cepat, tepat, akurat dan dapat dipertanggungjawabkan. Namun, kondisi saat ini menunjukkan bahwa ketersediaan informasi pasar yang terkini (up to date), real time dan komprehensif masih terbatas. Penyebab terbatasnya ketersediaan informasi pasar dapat dilihat pada Gambar 8 .

Faktor penyebab sistem informasi belum optimal dapat dilihat pada diagram fishbone yang disajikan dalam Gambar 9. Menurut Winarso (2003), penguasaan informasi cenderung dimiliki oleh sebagian pihak saja seperti para pedagang di pasarpasar besar. Hal ini disebabkan karena para pelaku pasar selalu mengikuti perkembangan dinamika pasar baik mengenai besarnya pasokan maupun meningkatnya permintaan yang setiap saat dapat bergejolak. Sedangkan petani belum sepenuhnya mengikuti perkembangan informasi yang terjadi di pasar. Sistem usahatani yang belum mengacu pada kebutuhan pasar, serta informasi yang terkadang bias di tingkat petani, maka harga bawang di tingkat petani tetap saja rendah.

\section{Distribusi Belum Berjalan dengan Baik}

Komoditas bawang merah sangat dibutuhkan oleh masyarakat Indonesia. Namun, tidak semua daerah di Indonesia dapat menghasilkan bawang merah. Untuk dapat mencapai konsumen, bawang merah memerlukan mekanisme distribusi yang baik dari sentra produksi hingga ke wilayah konsumen. Mekanisme distribusi yang baik mampu menggerakkan komoditas dari produsen ke konsumen dengan biaya yang serendah-rendahnya dan mampu memberikan pembagian yang adil dari keseluruhan harga yang dibayarkan konsumen kepada semua pihak yang terlibat di dalamnya.

Kondisi saat ini distribusi bawang merah belum berjalan dengan baik. Beberapa kendalanya antara lain fasilitas sarana dan prasarana distribusi belum mendukung (hal ini terkait dengan karakteristik bawang merah yang perishable dan bulky), jarak dari sentra produksi ke konsumen terlalu jauh, rantai pemasaran diluar sentra produksi terlalu panjang, dan lemahnya pengawasan saat distribusi.

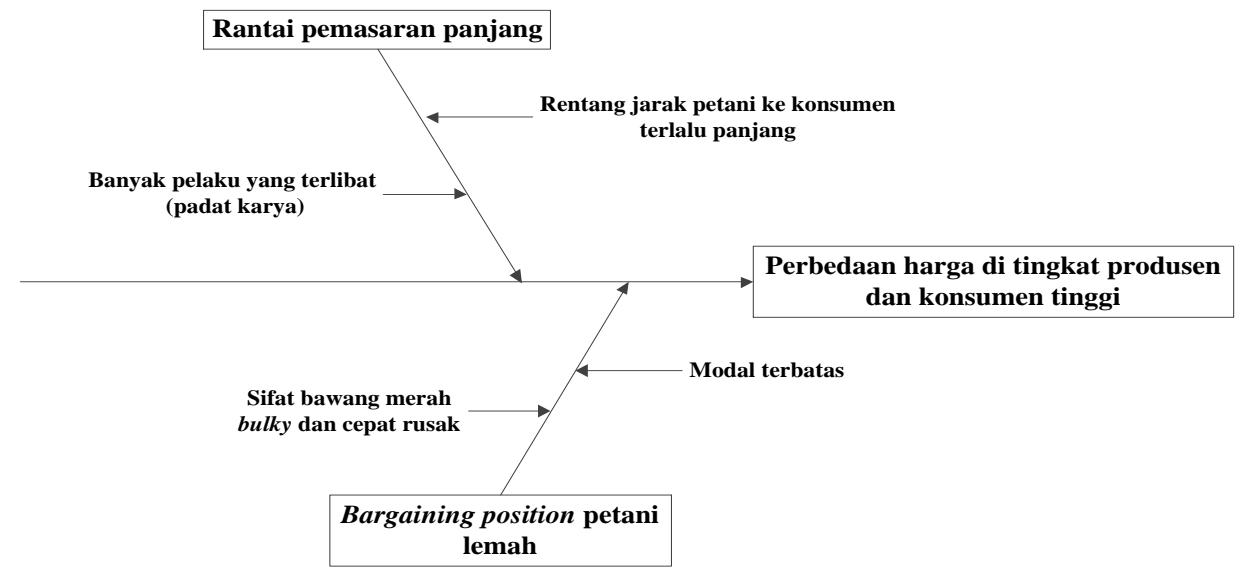

Gambar 7. Diagram fishbone penyebab perbedaan harga di tingkat produsen dengan harga di tingkat konsumen sangat jauh 


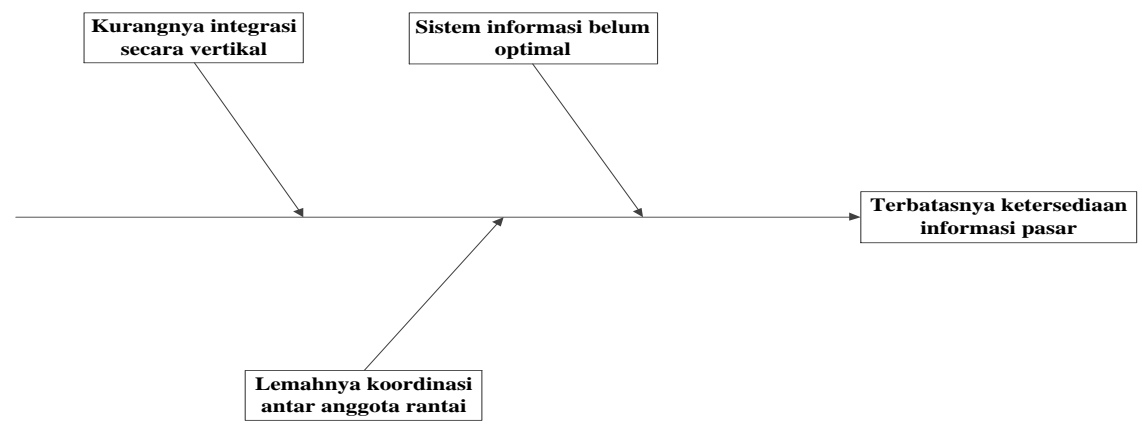

Gambar 8. Diagram fishbone penyebab terbatasnya ketersediaan informasi pasar

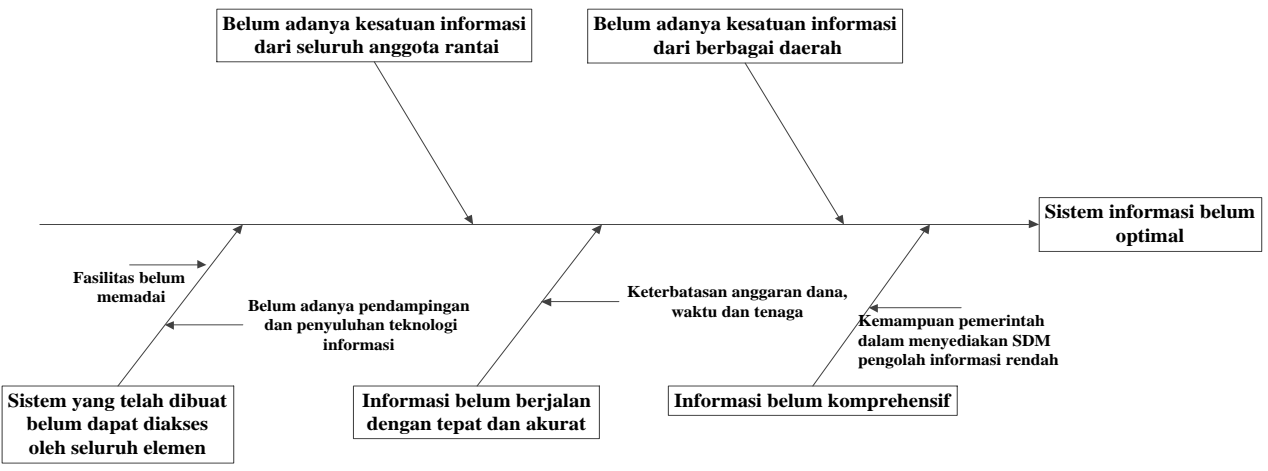

Gambar 9. Diagram fishbone penyebab sistem informasi belum optimal

Setelah diketahui faktor penyebab terjadinya rantai pasok bawang merah kurang efektif dan efisien, dilakukan pembobotan dengan menggunakan fuzzy AHP. Pembobotan dilakukan untuk melihat faktor penyebab yang memerlukan prioritas penanganan/pengelolaan. Hasil pembobotan dapat dilihat pada Tabel 7. Berdasarkan Tabel 7, masalah yang paling dominan mempengaruhi efektifitas dan efisiensi rantai pasok bawang merah adalah belum adanya sistem persediaan yang tepat disusul oleh adanya perbedaan harga yang sangat jauh antara harga di tingkat produsen dengan harga di tingkat konsumen. Prioritas penanganan selanjutnya adalah ketersediaan bawang merah yang rendah saat off season, sistem distribusi dan sistem informasi.

Tabel 7. Hasil pembobotan faktor penyebab rantai pasok bawang merah belum efektif dan efisien

\begin{tabular}{clc}
\hline Prioritas & Faktor penyebab & Bobot \\
\hline 1 & $\begin{array}{l}\text { Belum adanya sistem persediaan } \\
\text { yang tepat }\end{array}$ & 0,3838 \\
2 & $\begin{array}{l}\text { Perbedaan harga di tingkat } \\
\text { produsen dengan harga di } \\
\text { tingkat konsumen sangat jauh }\end{array}$ & 0,1802 \\
3 & $\begin{array}{l}\text { Ketersediaan bawang merah } \\
\text { rendah saat off season }\end{array}$ & 0,1704 \\
4 & $\begin{array}{l}\text { Distribusi belum berjalan } \\
\text { dengan baik }\end{array}$ & 0,1545 \\
5 & $\begin{array}{l}\text { Terbatasnya ketersediaan } \\
\text { informasi pasar }\end{array}$ & 0,1112 \\
\hline
\end{tabular}

\section{Upaya Peningkatan Kinerja Rantai Pasok Bawang Merah}

Berdasarkan hasil analisis kesenjangan dan analisis masalah yang merujuk pada hasil analisis kondisi dan pengukuran kinerja rantai pasok bawang merah di Kabupaten Brebes, maka disusun upayaupaya dalam rangka memenuhi tujuan peningkatan kinerja rantai pasok bawang merah di Kabupaten Brebes. Upaya tersebut antara lain:

1. Membangun sistem persediaan yang tepat. Langkah-langkah untuk merealisasikan usaha tersebut diantaranya:
a. Fasilitasi peralatan maupun teknologi penyimpanan

b. Penyuluhan mengenai adopsi teknologi

c. Revitalisasi dan optimalisasi gudang penyimpanan yang ada di Brebes

d. Pengembangan penelitian mengenai sistem persediaan bawang merah

e. Pengembangan teknologi benih tahan iklim dan tahan OPT

f. Pemanfaatan dan akses program Sistem Resi Gudang (SRG)

2. Mengurangi perbedaan harga yang sangat jauh antara harga ditingkat produsen dengan harga ditingkat konsumen. Langkah-langkah yang dapat dilakukan antara lain dengan

a. Membangun kemitraan, koordinasi dan kolaborasi diantara anggota rantai

b. Penguatan kelembagaan petani 
c. Penerapan Sistem Resi Gudang (SRG), Toko Tani Indonesia (TTI), dan Rumah Pangan Kita (RPK)

3. Mengatasi rendahnya ketersediaan bawang merah terutama saat off season. Usaha yang dapat ditempuh, diantaranya:

a. Pembuatan waduk di daerah hulu sebagai tempat penampungan air hujan

b. Pembuatan sistem drainase pada lahan budidaya bawang merah

c. Penggunaan mulsa pada lahan tanam bawang merah

d. Pengembangan teknik pengendalian OPT

e. Pembuatan pola tanam yang terintegrasi antar komoditas dan antar daerah

f. Penyuluhan dan pendampingan yang lebih intensif serta demonstrasi plot (demplot)

g. Penggunaan pupuk organik

h. Perbaikan pada kemasan bawang merah yang digunakan

i. Pengembangan teknik penyimpanan benih

j. Penyuluhan dan pendampingan serta fasilitasi peralatan pascapanen

k. Adanya kebijakan dari Pemerintah dalam penetapan harga benih

1. Pemberian Kartu Tani untuk petani kecil

m. Adanya regulasi yang mengatur transaksi (tempat, volume dan kualitas) dan metode pembayaran, serta peraturan lainnya

4. Meningkatkan ketersediaan informasi pasar. Upaya yang dapat dilakukan yaitu menggalang keterlibatan masyarakat dalam penyediaan informasi, serta mengembangkan dan mengaplikasikan teknologi sistem informasi yang mencakup seluruh aspek rantai pasokan (harga, jumlah pasokan, permintaan, dan lainnya) serta adopsi teknologi informasi.

5. Mengatasi permasalahan mengenai mekanisme distribusi. Usaha yang dapat dilakukan adalah dengan menggunakan sarana transportasi yang efektif dan efisien.

Keterkaitan antara masalah, penyebab dasar dan upaya peningkatan kinerja rantai pasok bawang merah di Kabupaten Brebes dapat dilihat dalam matrik yang disajikan pada Tabel 8 .

\section{KESIMPULAN DAN SARAN}

\section{Kesimpulan}

Rantai pasok bawang merah dari produsen hingga konsumen akhir memiliki aliran yang panjang dan saluran yang beragam. Pelaku rantai pasok bawang merah yang terdapat di Kabupaten Brebes hanya terdiri dari petani, pedagang pengumpul, pedagang besar, dan pedagang pengecer lokal atau pedagang pasar tradisional lokal. Pola saluran pasokan yang terbentuk umumnya telah berjalan dalam jangka waktu yang lama dan terbentuk secara alami. Kondisi sumber daya fisik khususnya gudang penyimpanan tidak berfungsi sebagaimana mestinya.

Kemampuan anggota rantai dalam pengusahaan (produksi, distribusi, pemasaran) bawang merah ditentukan oleh permodalan. Pelaku rantai pasok bawang merah terutama petani, akan memasok bawang merah sesuai jumlah rmodalyang dimiliki. Pelaku yang memiliki modal besar mampu memenuhi permintaan pasar.

Kinerja rantai pasok bawang merah di Kabupaten Brebes pada saat in season lebih besar (skor 3,57) dibandingkan saat off season (skor 3,28). Pada saat in season kinerja petani (skor 3,39) lebih rendah dibandingkan kinerja pedagang pengumpul (skor 3,49) dan pedagang besar (skor 3,84) sedangkan pada saat off season kinerja pedagang pengumpul (skor 3,14) lebih rendah dibandingkan petani (skor 3,20) dan pedagang besar (skor 3,50). Secara umum, kinerja pedagang besar lebih baik dibandingkan petani dan pedagang pengumpul pada kedua musim.

Upaya dalam rangka meningkatkan kinerja rantai pasok bawang merah di Kabupaten Brebes antara lain membangun sistem persediaan yang tepat; mengurangi perbedaan harga yang sangat jauh antara harga ditingkat produsen dan harga ditingkat konsumen dengan membangun kemitraan, koordinasi dan kolaborasi diantara anggota rantai serta penguatan kelembagaan petani, mengatasi rendahnya ketersediaan bawang merah terutama saat off season; meningkatkan ketersediaan informasi pasar; serta mengatasi permasalahan mengenai mekanisme distribusi.

\section{Saran}

Penelitian lebih lanjut perlu dikembangkan dengan memperluas ruang lingkup penelitian dari produsen hingga konsumen akhir.

\section{DAFTAR PUSTAKA}

Adiyoga W, Ameriana M, dan Setiawati W. 2010. Perancangan perbaikan SCM bawang merah [Internet]. Bandung (ID): Balai Penelitian Tanaman Sayuran. [diunduh 2015 Maret 4]. Tersedia pada: https://www.scribd.com/doc/ 44637630/Perancangan-Perbaikan-SupplyChain-Management-SCM-Bawang-Merah.

Arin RDN, Astuti R, dan Ikasari DM. 2013. Penilaian kinerja pemasok susu segar menggunakan metode analytic network process dan rating scale: studi kasus di pusat koperasi industri susu sekar tanjung pasuruan. Jurnal Teknologi Pertanian. 14(2): 131-140.

Bhagwat R dan Sharma MK. 2007. Performancemeasurement of Supply Chain Management: a balanced scorecard approach. Computers \& Industrial Engineering.53: 4362. doi: 0.1016/j.cie.2007.04.001. 
Tabel 8 . Matriks masalah, penyebab dan upaya peningkatan kinerja

\begin{tabular}{|c|c|c|c|c|}
\hline No & Masalah & Penyebab dasar & Akar penyebab & Upaya \\
\hline \multirow[t]{7}{*}{1} & \multirow[t]{7}{*}{ Sistem persediaan belum ada } & \multirow{4}{*}{$\begin{array}{l}\text { 1. Belum diterapkannya } \\
\text { sistem penyimpanan yang } \\
\text { tepat }\end{array}$} & 1. Aspek ekonomi (mahalnya teknologi) & $\begin{array}{l}\text { Subsidi atau bantuan (fasilitasi) } \\
\text { peralatan/ teknologi }\end{array}$ \\
\hline & & & $\begin{array}{ll}2 . & \text { Kesadaran masyarakat akan penerapan } \\
\text { teknologi masih minim }\end{array}$ & Penyuluhan mengenai adopsi teknologi \\
\hline & & & $\begin{array}{l}\text { 3. Kurangnya sosialisasi ataupun bimbingan } \\
\text { mengenai teknologi tepat guna }\end{array}$ & \\
\hline & & & $\begin{array}{l}\text { 4. Masyarakat masih mempertimbangkan tingkat } \\
\text { kepraktisan dari sebuah teknologi }\end{array}$ & \\
\hline & & $\begin{array}{l}\text { 2. Fasilitas penyimpanan } \\
\text { belum termanfaatkan } \\
\text { dengan baik }\end{array}$ & \multirow[t]{2}{*}{$\begin{array}{l}\text { Gudang penyimpanan tidak berfungsi sebagaimana } \\
\text { mestinya }\end{array}$} & $\begin{array}{l}\text { Revitalisasi dan optimalisasi gudang } \\
\text { penyimpanan yang ada di Brebes }\end{array}$ \\
\hline & & $\begin{array}{l}\text { 3. Belum adanya penelitian } \\
\text { tentang sistem persediaan } \\
\text { bawang merah }\end{array}$ & & $\begin{array}{l}\text { Pengembangan penelitian mengenai } \\
\text { sistem persediaan bawang merah }\end{array}$ \\
\hline & & $\begin{array}{l}\text { Perencanaan produksi } \\
\text { yang belum terlaksana } \\
\text { dengan baik }\end{array}$ & Anomali iklim & $\begin{array}{l}\text { Pengembangan teknologi benih tahan } \\
\text { iklim }\end{array}$ \\
\hline 2 & $\begin{array}{l}\text { Perbedaan harga di tingkat } \\
\text { produsen dengan harga di tingkat } \\
\text { konsumen sangat jauh }\end{array}$ & Rantai pemasaran panjang & Melibatkan banyak pelaku (padat karya) & $\begin{array}{l}\text { Membangun kemitraan, koordinasi dan } \\
\text { kolaborasi diantara anggota rantai }\end{array}$ \\
\hline \multirow[t]{3}{*}{3} & \multirow[t]{3}{*}{$\begin{array}{l}\text { Ketersediaan bawang merah } \\
\text { rendah terutama saat off season }\end{array}$} & \multirow[t]{3}{*}{$\begin{array}{l}\text { 1. Hasil panen bawang merah } \\
\text { rendah saat off season }\end{array}$} & $\begin{array}{l}\text { 1. Saat off season tanaman bawang merah } \\
\text { kelebihan air karena dampak hujan }\end{array}$ & $\begin{array}{l}\text { 1. Pembuatan waduk di daerah hulu } \\
\text { sehingga air hujan dapat ditampung } \\
\text { 2. Pembuatan sistem drainase } \\
\text { 3. Penggunaan mulsa atau penutup } \\
\text { lainnya pada lahan tanam bawang } \\
\text { merah }\end{array}$ \\
\hline & & & $\begin{array}{ll}2 . & \text { Tanaman bawang merah terkena serangan } \\
\text { OPT }\end{array}$ & $\begin{array}{l}\text { Pengembangan teknik pengendalian } \\
\text { OPT }\end{array}$ \\
\hline & & & $\begin{array}{l}\text { 3. Terjadinya alih fungsi lahan dengan adanya } \\
\text { penanaman komoditas lain }\end{array}$ & $\begin{array}{l}\text { Pembuatan pola tanam yang terintegrasi } \\
\text { antar daerah dan antar komoditas }\end{array}$ \\
\hline
\end{tabular}




\begin{tabular}{|c|c|c|c|c|}
\hline No & Masalah & Penyebab dasar & Akar penyebab & Upaya \\
\hline & & $\begin{array}{l}\text { 2. Sebagian besar petani } \\
\text { tidak menggunakan SOP } \\
\text { budidaya }\end{array}$ & $\begin{array}{l}\text { Sikap yang tertutup karena tidak mau } \\
\text { menggunakan teknologi baru) }\end{array}$ & $\begin{array}{l}\text { Penyuluhan dan pendampingan yang } \\
\text { lebih intensif serta demonstrasi plot } \\
\text { (demplot) }\end{array}$ \\
\hline & & $\begin{array}{l}\text { 3. Tingkat kesuburan lahan } \\
\text { menurun }\end{array}$ & Pemakaian pupuk buatan/anorganik tinggi & $\begin{array}{l}\text { Penggunaan pupuk organik (subsidi } \\
\text { pupuk organik) }\end{array}$ \\
\hline & & $\begin{array}{l}\text { 4. Kemampuan memutar } \\
\text { siklus kas rendah }\end{array}$ & $\begin{array}{l}\text { Sistem pembayaran yang tidak tunai dalam } \\
\text { pembayaran (Bargaining position lemah) }\end{array}$ & $\begin{array}{l}\text { - Adanya regulasi yang mengatur } \\
\text { transaksi (tempat, volume dan } \\
\text { kualitas) dan metode pembayaran, } \\
\text { serta peraturan lainnya } \\
\text { - Penguatan kapasitas petani dan } \\
\text { kelembagaan petani }\end{array}$ \\
\hline & & $\begin{array}{l}\text { 5. Tingkat kerusakan bawang } \\
\text { merah tinggi }\end{array}$ & 1. Teknik pascapanen masih konvensional & $\begin{array}{l}\text { Penyuluhan dan pendampingan serta } \\
\text { fasilitasi peralatan pascapanen }\end{array}$ \\
\hline & & & $\begin{array}{ll}\text { 2. } & \text { Sistem kemasan saat proses transportasi dan } \\
\text { distribusi }\end{array}$ & Perbaikan pada kemasan yang digunakan \\
\hline & & 6. Biaya produksi tinggi & $\begin{array}{l}\text { 1. Harga benih tinggi, karena: } \\
\text { a. Terjadi penyusutan selama penyimpanan } \\
\text { b. Penyimpanan benih memakan tempat dan } \\
\text { waktu (bulky) } \\
\text { c. Penyimpanan menggunakan bahan pengawet } \\
\text { karena sifat bawang merah yang cepat busuk }\end{array}$ & $\begin{array}{l}\text { Pengembangan teknik penyimpanan } \\
\text { benih atau teknologi benih }\end{array}$ \\
\hline & & & $\begin{array}{l}\text { d. Harga benih bergantung pada harga bawang } \\
\text { merah awal (saat panen) }\end{array}$ & $\begin{array}{l}\text { Adanya kebijakan dari Pemerintah } \\
\text { dalam penetapan harga benih }\end{array}$ \\
\hline & & & $\begin{array}{l}\text { 2. Biaya input seperti pupuk dan obat-obatan } \\
\text { tinggi }\end{array}$ & $\begin{array}{l}\text { Pemberian KARTU TANI pada petani } \\
\text { khusunya }\end{array}$ \\
\hline \multirow[t]{2}{*}{4} & $\begin{array}{l}\text { Terbatasnya ketersediaan } \\
\text { informasi pasar }\end{array}$ & $\begin{array}{l}\text { 1. Informasi belum } \\
\text { komprehensif }\end{array}$ & $\begin{array}{l}\text { Kemampuan pemerintah dalam menyediakan } \\
\text { SDM pengolah informasi rendah }\end{array}$ & $\begin{array}{l}\text { Menggalang keterlibatan masyarakat } \\
\text { (LSM) dalam penyediaan informasi } \\
\text { pasar }\end{array}$ \\
\hline & & $\begin{array}{l}\text { 2. Informasi belum berjalan } \\
\text { dengan tepat dan akurat }\end{array}$ & Keterbatasan anggaran dana, waktu dan tenaga & $\begin{array}{l}\text { Pengembangan dan aplikasi teknologi } \\
\text { informasi }\end{array}$ \\
\hline 5 & $\begin{array}{l}\text { Distribusi belum berjalan dengan } \\
\text { baik }\end{array}$ & $\begin{array}{l}\text { Fasilitas sarana dan prasarana } \\
\text { distribusi belum memadai }\end{array}$ & & $\begin{array}{l}\text { Penggunaan sarana transportasi yang } \\
\text { efektif dan efisien }\end{array}$ \\
\hline
\end{tabular}


Christopher M. 2011. Logistic and Supply Chain Management, fourth edition. London (GB): Pearson Prentice Hall.

Dinata H, Suryani E, dan Hendrawan RA. 2014. Peningkatan kinerja sistem rantai pasok di industri perikanan untuk ketahanan pangan. Jurnal Sistem Informasi. 5(2): 86-94.

Fan X, Zhaing S, Wang L, Yang Y, Hapeshi K. 2013. An evaluation model of supply chain performances using 5DBSC and LMBP neural network algorithm. Journal of Bionic Engineering. 10: 383-395.

Heizer J dan Reinder B. 2010. Manajemen Operasi, Edisi 9. Jakarta (ID): Salemba Empat.

Jannah RZ, Subagja H, dan Rujito H. 2015. Optimalisasi kinerja rantai pasokan dan rantai nilao tembakau Kasturi (voor oogost) di Kabupaten Jember. Jurnal Teknologi Pertanian. 16 (1): 51-64.

Marimin, Djatna T, Suharjito, Hidayat S, Utama DN, Astuti R, Martini S. 2013. Teknik dan Analisis Pengambilan Keputusan Fuzzy dalam Manajemen Rantai Pasok. Bogor (ID): IPB Press.

Marimin dan Maghfiroh N. 2010. Aplikasi Teknik Pengambilan Keputusan dalam Manajemen Rantai Pasok. Bogor (ID): IPB Press.

Nagurney A, Yu Min Masoumi AH, Nagurney LS. 2013. Networks Against Time Supply Chain, Supply Chain Analytics For Perishable Products. New York (US): Springer.

Nurasa T dan Darwis V. 2007. Analisis usahatani dan keragaan marjin pemasaran bawang merah di Kabupaten Brebes. J Akta Agr. 10(1): 40-48.
Paul J. 2014. Panduan Penerapan; Transformasi Rantai Suplai dengan Model SCOR. Jakarta (ID): PPM Manajemen.

[Pusdatin] Pusat Data dan Sistem Informasi Pertanian. 2015. Outlook Bawang Merah. Jakarta (ID): Pusat Data dan Sistem Informasi Pertanian, Kementerian Pertanian.

Setiawan A, Marimin, Arkeman Y, Udin F. 2011. Studi peningkatan kinerja manajemen rantai pasok sayuran dataran tinggi di Jawa Barat. JurnalAgritech. 31(1): 60-70.

Sucipta IM, Widia IW, dan Utama IMS. 2016. Strategi peningkatan kinerja manajemen rantai pasokan jeruk siam di kelompok tani Gunung Mekar Kabupaten Gianyar. Biosistem dan Teknik Pertanian (BETA). 4(2): 27-35.

Thakkar J, Kanda A, dan Deskhmukh SG. 2009. Supply chain performance measurement framework for small and medium scale enterprises. Benchmarking: An International Journal. 16 (5): 702-723.

Van der Vorst JGAJ. 2006. Performance measurement in agri-food supply chain networks, an overview. Logistics and Operations Research Group, Wageningen University, Hollandseweg 1, $6706 \mathrm{KN}$ Wageningen, The Netherlands.

Winarso B. 2003. Dinamika perkembangan harga: hubungannya dengan tingkat keterpaduan antar pasar dalam efisiensi pemasaran komoditas bawang merah. Jurnal Ilmiah Kesatuan. 4(1-2).7-16. 